\title{
Lingkungan Pengendapan Formasi Tanjung di Lintasan Gunungbatu, Binuang,
} Kalimantan Selatan

\section{Depositional Environment of Tanjung Formation Along Gunungbatu Traverse, Binuang, South Kalimantan}

\author{
M. Luthfi Faturrakhman, Jamal Jamal, Sigit Maryanto, dan Nela P. Rattyananda \\ Pusat Survei Geologi, Badan Geologi, J1. Diponegoro No. 57 Bandung, 40122 \\ e-mail: m.luthfifatur@gmail.com \\ Naskah diterima : 19 April 2021, Revisi terakhir :30 Agustus 2021 Disetujui :30 Agustus 2021, Online : 30 Agustus 2021 \\ DOI: http://dx.doi.org/10.33332/jgsm.geologi.22.3.133-141p
}

\begin{abstract}
Abstrak-Pengkajian aspek lingkungan pengendapan terhadap batuan sedimen klastika penyusun Formasi Tanjung di Gunungbatu menarik karena batuan tersingkap baik di lokasi ini. Batuan ini tersingkap di tebing dan selokan jalan, perlapisan batuan miring sedang hingga curam ke arah barat-baratlaut, tebal lapisan terukur mencapai $160 \mathrm{~m}$. Batuan yang dijumpai di lintasan ini secara umum berupa batupasir yang berselingan dengan batulempung, dan sisipan batubara. Batuan pada awalnya merupakan hasil endapan sungai, khususnya wilayah limpasan. Lingkungan pengendapan berkembang menjadi wilayah limpah banjir, khususnya di cekungan banjir yang sering terganggu akibat banjir. Selanjutnya, lingkungan pengendapan batuan lebih menuju ke laut, meskipun masih berada di lingkungan fluvial hingga daerah rawa pada dataran delta, dengan pengaruh laut. Batuan sumber formasi ini terangkut dan terendapkan di cekungan pengendapan di bagian timurtenggara.
\end{abstract}

Katakunci: Formasi Tanjung, klastika, limpah banjir, rawa, sedimentologi.

\begin{abstract}
Depositional environment study of the clastic sedimentary rock from Tanjung Formation at Gunungbatu is interesting because the rocks exposed well enough in this location. The rocks cropped out in cliffs and street gutter, the rocks moderately to steeply dipping toward west-northwest, and measurable reached up to $160 \mathrm{~m}$ thick. The rocks discovered in this traverse consist of sandstone and claystone interlayers with coal intercalations. At the first the rock is the result of river sediment, especially overbank area. The deposition environment develops into a floodplain deposit, especially in the flood basin, who often disrupted by flooding. Furthermore, the deposition of the rocks tend towards to the sea although it was located within the fluvial until the marshes of delta plain with marine influence. Source rocks of this formation was transported and deposited in the basin environment in the eastsoutheastern part.
\end{abstract}

Keywords: Tanjung Formation, clastic, floodplain, marsh, sedimentology. 


\section{PENDAHULUAN}

Kegiatan pemetaan geologi berskala 1:50.000 di Lembar Binuang, Kalimantan Selatan (Gambar 1) dilakukan oleh Pusat Survei Geologi pada tahun 2014. Pada saat dilakukan pemetaan lapangan (Kusumah dkk., 2016), di daerah ini dijumpai satu lokasi yang menyingkapkan batuan penyusun Formasi Tanjung, yaitu di Gunungbatu. Pengkajian aspek sedimentologi terhadap satuan batuan di lokasi ini cukup menarik untuk dilakukan karena batuan tersingkap cukup baik dan lengkap, yang mewakili kehadiran Formasi Tanjung. Penelitian ini bertujuan untuk mengetahui perkembangan lingkungan pengendapan satuan batuan yang tersingkap. Identifikasi lingkungan pengendapan satuan batuan ini didasarkan kepada karakter litologi dan stratigrafi di lapangan, seperti jenis batuan, geometri dan struktur sedimen, yang didukung oleh penelitian terdahulu mengenai aspek sedimentologi dan lingkungan pengendapan.

Geologi regional daerah pemetaan telah dibahas dalam Heryanto (2010), yang menyatakan bahwa Cekungan Barito ditempati oleh batuan yang mempunyai beragam umur. Batuan tertua di daerah ini adalah Granit Belawayan yang merupakan bagian dari kerak benua (Dirk \& Amiruddin, 2009), selain batuan malihan sekis (Setiawan dkk., 2015), dan batuan ultramafik (Sunarjanto \& Widjaja, 2013). Batuan tersebut tertindih oleh batugamping Formasi Batununggal yang berumur Kapur Awal, baik sebagai autokton maupun alokton (Maryanto dkk., 2014). Selanjutnya Batuan Kapur Akhir tersingkap di daerah penelitian, yang terdiri atas batuan sedimen klastika Formasi Pudak, Formasi Keramaian, Formasi Manunggul, Formasi Pitanak, dan Formasi Paau (Heryanto dkk., 1998). Batuan Paleogen-Neogen (Margono, 2012; Margono dkk., 1997; Heryanto dkk., 1998; Kusumah dkk., 2016; Gambar 2) diawali dengan terendapkannya batuan silisiklastika Formasi Tanjung yang berumur Eosen Akhir, diikuti oleh batugamping Formasi Berai yang berumur OligosenMiosen, batuan silisiklastika Formasi Warukin yang berumur Miosen Tengah, dan batuan silisiklastika Formasi Dahor yang berumur Plio-Plistosen.

Formasi Tanjung secara umum terbagi atas tiga bagian dan satu anggota (Heryanto, 2010; 2014). Bagian bawah tersusun oleh batupasir hingga konglomerat yang diendapkan di lingkungan fluvial. Bagian tengah berupa batulempung dengan sisipan batubara yang diendapkan di lingkungan dataran banjir hingga rawa. Bagian atas tersusun oleh perselingan batulanau dan batupasir yang diendapkan di lingkungan delta. Anggota batulempung tersusun oleh batulempung dengan sisipan tipis batupasir gampingan. Runtunan batuan seperti tersebut relatif sama di seluruh Cekungan Barito (Witts dkk., 2012).

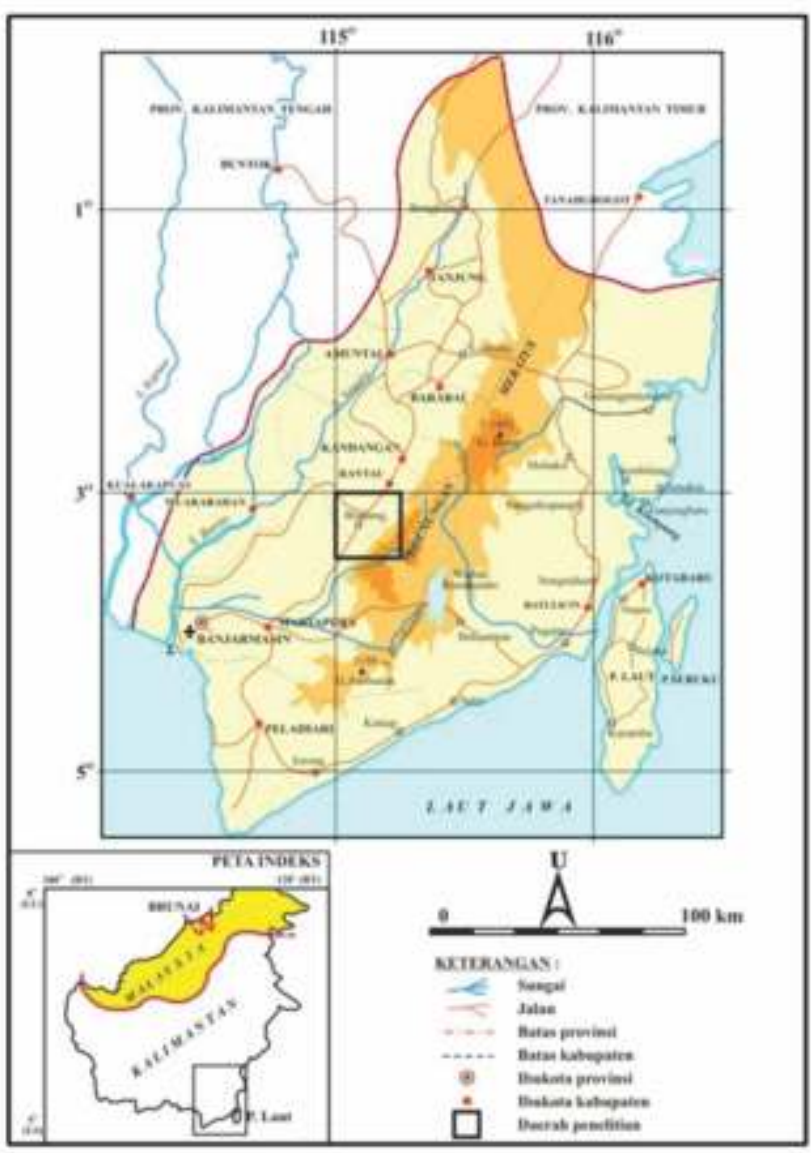

Gambar 1. Lokasi daerah penelitian di daerah Binuang, Kalimantan Selatan.

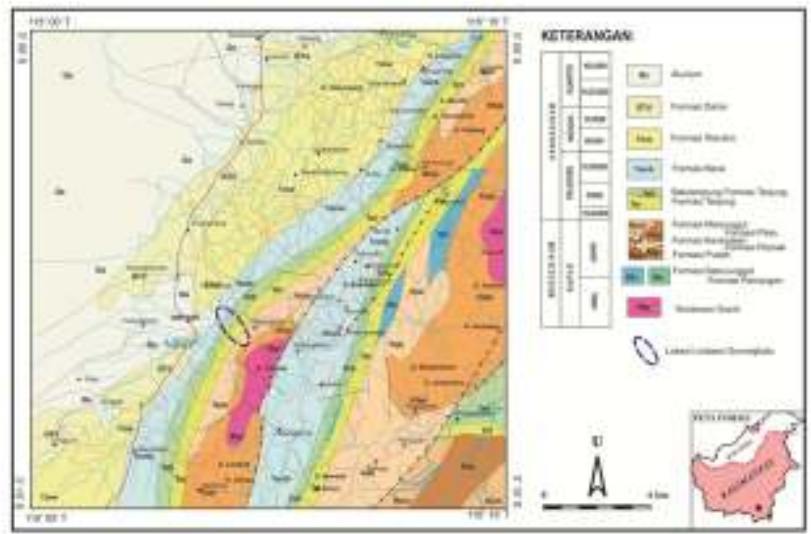

Sumber:Heryanto dkk., 1998; Kusumah dkk.,2016

Gambar 2. Peta Geologi Daerah Binuang dan lokasi Lintasan Gunungbatu. 


\section{KENAMPAKAN LAPANGAN}

Lintasan pengukuran stratigrafi rinci di Desa Gunungbatu dimulai pada koordinat $115^{\circ} 06^{\prime} 45.1^{\prime \prime}$ Bujut Timur dan $03^{\circ} 09^{\prime} 21.3^{\prime \prime}$ Lintang Selatan, ke arah barat menyusuri jalan sepanjang sekitar $2 \mathrm{~km}$. Batuan sedimen klastika tersingkap dengan baik di tebing dan selokan jalan sepanjang lintasan ini, perlapisan batuan miring sedang hingga curam ke arah barat-baratlaut, dan tebal lapisan terukur mencapai $160 \mathrm{~m}$ (Gambar3).

Bagian awal pengukuran (di bagian timur) ditemukan batupasir vulkanik dalam kondisi sangat lapuk, berwarna kecoklatan, terkekarkan cukup intensif, tebal minimal $3 \mathrm{~m}$ (Gambar 4). Batuan ini diduga merupakan penyusun Formasi Keramaian yang berumur Kapur Akhir (lihat Gambar 3a). Di atas batupasir vulkanik tersebut diendapkan batuan sedimen klastika penyusun Formasi Tanjung. Hubungan antar kedua formasi ini tidak teramati dengan baik akibat rusak tersesarkan. Bagian terbawah batuan penyusun Formasi Tanjung diawali oleh hadirnya batupasir abu-abu sangat terang kecoklatan, berlapis susun dan bagian atas menjadi perarian sejajar, ukuran butir kasar hingga sangat halus, sangat jarang masih mengandung oksida besi, tebal 180-340 cm (Gambar 5). Selanjutnya, batuan berkembang menjadi perselingan batupasir dan batulempung. Batupasir berwarna abu-abu terang kecoklatan, pejal dan berlapis susun tebal, kadang masih mengandung oksida besi, terpilah buruk, butiran membundar tanggung, tebal $320-340 \mathrm{~cm}$. Batulempung berwarna abu-abu terang kecoklatan, pejal, tebal mencapai $380 \mathrm{~cm}$, dan sering berkembang menjadi batupasir sangat halus berstruktur perarian sejajar. Ketebalan total bagian terbawah ini mencapai $22 \mathrm{~m}$.

Runtunan batuan sedimen klastika penyusun Formasi Tanjung bawah masih berupa batupasir yang berwarna abu-abu terang kecoklatan, berlapis susun tebal yang bagian atasnya menjadi perarian sejajar, dengan bintal oksida besi, bagian bawah lapisan konglomeratan, terpilah buruk, butiran membundar tanggung berukuran mencapai $0,5 \mathrm{~cm}$, tebal $540 \mathrm{~cm}$. Batuan berkembang menjadi batulempung abu-abu terang sedikit kecoklatan, pejal dan beberapa bagian berstruktur perarian sejajar, mengandung bintal oksida besi , tebal 5-100 $\mathrm{cm}$, berselingan dengan batupasir abu-abu sangat terang kecoklatan, ukuran pasir halus hingga sangat halus, struktur perarian sejajar (Gambar 6), dengan bintal oksida besi, tebal 5$50 \mathrm{~cm}$. Selanjutnya terjadi perulangan, batuan kembali menjadi batupasir berwarna abu-abu terang hingga abu-abu sangat terang kecoklatan, berlapis susun, perarian sejajar, bergelombang, silang-siur, ukuran butir kasar hingga sangat halus, terpilah sedang hingga buruk, beberapa mengandung sedikit bintal oksida besi, tebal $60-600 \mathrm{~cm}$, sangat jarang sisipan tipis batulempung abu-abu terang, pejal, tebal $5-10 \mathrm{~cm}$. Ketebalan total bagian bawah ini mencapai $40 \mathrm{~m}$.

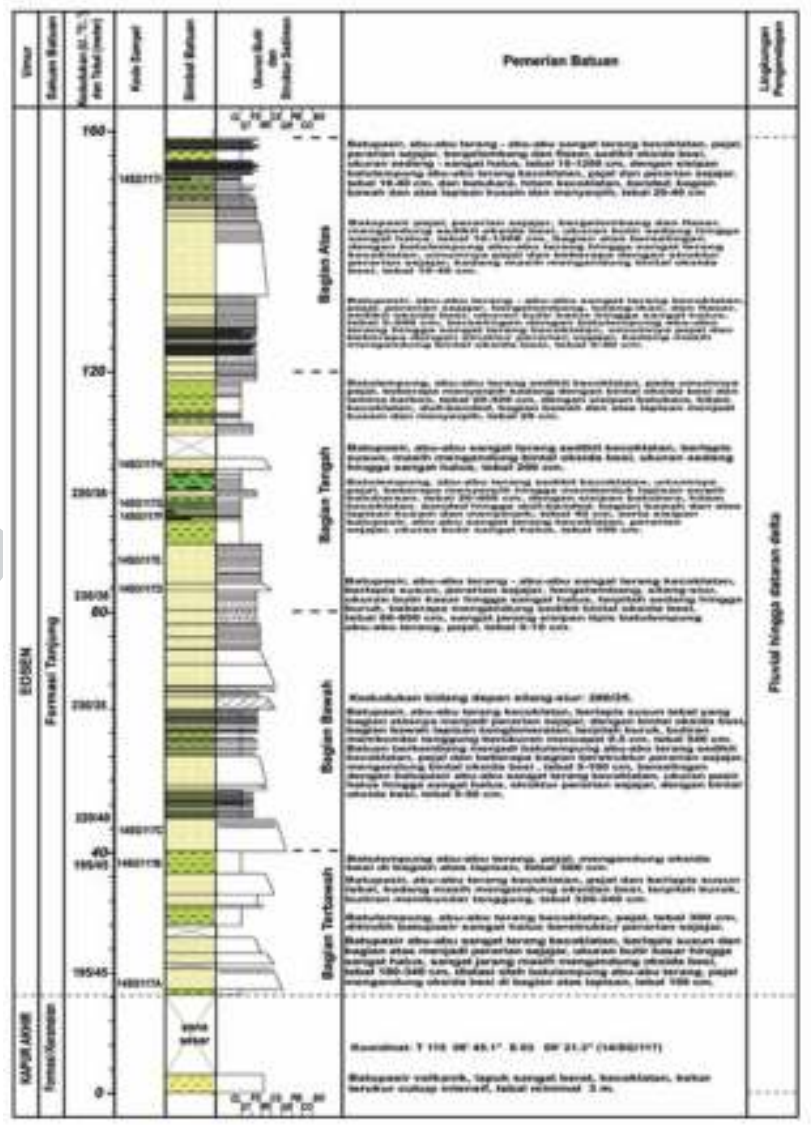

Gambar 3. Kolom stratigrafi rinci di Lintasan Gunungbatu, Binuang, Kalimantan Selatan.

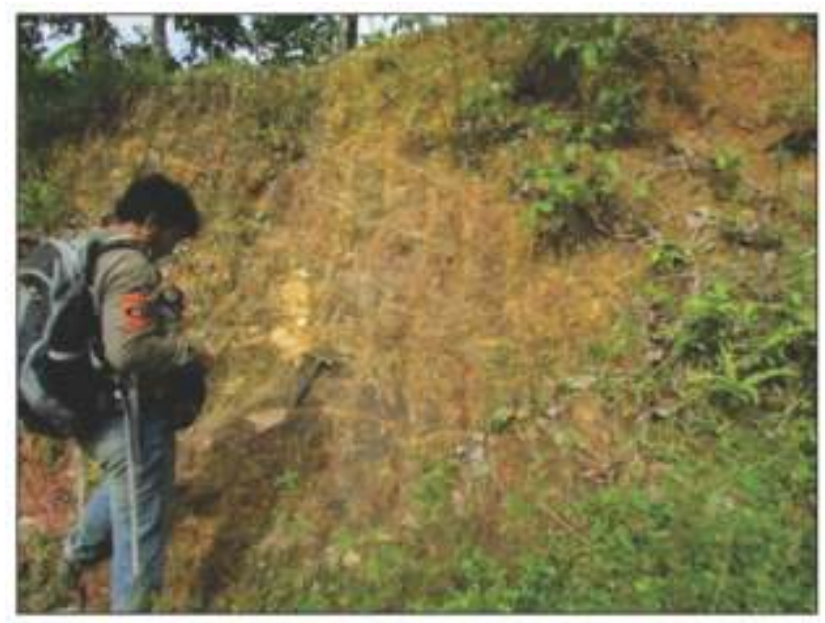

Gambar 4. Singkapan batupasir vulkanik penyusun Formasi Keramaian yang tertindih takselaras batupasir Formasi Tanjung. 


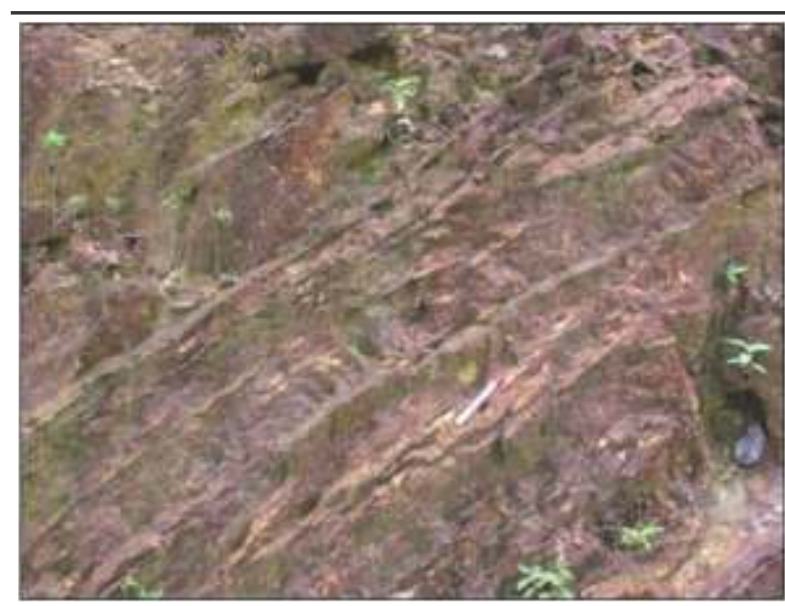

Gambar 5. Singkapan batupasir penyusun bagian terbawah Formasi Tanjung yang berbutir kasar hingga halus berstruktur berlapis susun, merupakan hasil pengendapan saluran (channel).

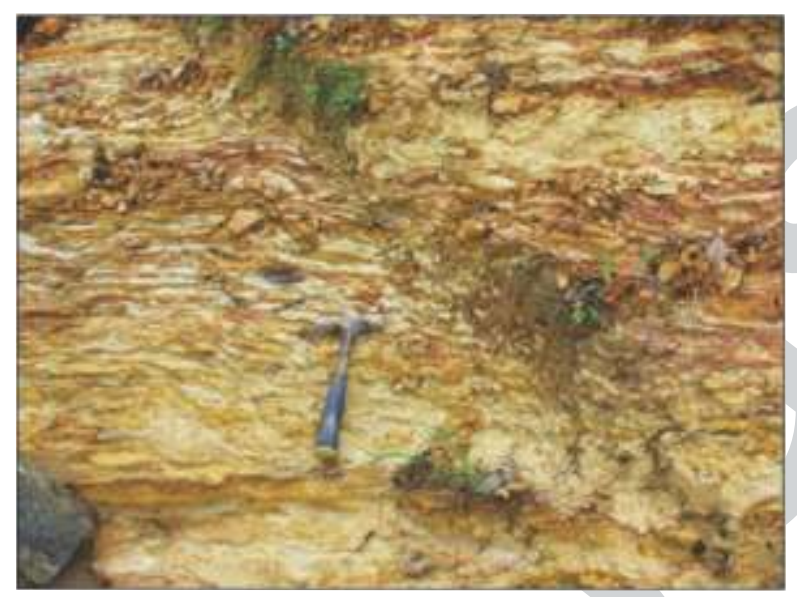

Gambar 6. Batupasir halus hingga sangat halus berstruktur perarian sejajar dan bergelombang penyusun bagian bawah Formasi Tanjung, yang merupakan endapan limpah banjir dengan crevasse splay.

Bagian tengah runtunan batuan (lihat Gambar 3c) berupa batulempung berselingan dengan batupasir dengan sisipan batubara. Mengawali runtunan, hadir batupasir abu-abu terang hingga abu-abu sangat terang kecoklatan, berlapis susun, perarian sejajar, bergelombang, silang-siur (Gambar 7), ukuran butir kasar hingga sangat halus, terpilah sedang hingga buruk, beberapa mengandung sedikit bintal oksida besi, tebal $60-600 \mathrm{~cm}$, sangat jarang sisipan tipis batulempung abu-abu terang, pejal, tebal $5-10 \mathrm{~cm}$. Selanjutnya, batuan berkembang menjadi batulempung abu-abu terang sedikit kecoklatan, umumnya pejal, beberapa menyerpih hingga membentuk lapisan serpih batubaraan, tebal 20-400 $\mathrm{cm}$, dengan sisipan batubara, hitam kecoklatan, banded hingga dull-banded, bagian bawah dan atas lapisan kusam dan menyerpih, tebal $40 \mathrm{~cm}$, serta sisipan batupasir, abu-abu sangat terang kecoklatan, perarian sejajar, ukuran butir sangat halus, tebal $100 \mathrm{~cm}$ (Gambar 8). Runtunan batulempung yang beberapa menyerpih dan kadang dengan bintal oksida besi danlamina karbon dengan tebal $20-420 \mathrm{~cm}$ masih hadir mengakhiri bagian tengah runtunan batuan. Selain itu, sisipan batubara hadir berwarna hitam kecoklatan, dullbanded, bagian bawah dan atas lapisan menjadi kusam dan menyerpih, tebal $20 \mathrm{~cm}$. Tebal keseluruhan bagian tengah Formasi Tanjung ini mencapai $40 \mathrm{~m}$.

Bagian atas runtunan batuan (lihat Gambar 3d) diawali dengan hadirnya batupasir abu-abu terang hingga abuabu sangat terang kecoklatan, pejal, perarian sejajar, bergelombang, tulang-ikan (Gambar 9), dan flaser, sedikit oksida besi, ukuran butir halus hingga sangat halus, tebal $5-200 \mathrm{~cm}$, berselingan dengan batulempung abu-abu terang hingga sangat terang kecoklatan, umumnya pejal dan beberapa dengan struktur perarian sejajar, kadang masih mengandung bintal oksida besi, tebal $5-40 \mathrm{~cm}$. Selanjutnya, batuan berkembang menjadi batupasir pejal, perarian sejajar, bergelombang dan flaser, mengandung sedikit oksida besi, ukuran butir sedang hingga sangat halus, tebal $10-1200 \mathrm{~cm}$, bagian atas dengan sisipan batulempung abu-abu terang berstruktur perarian sejajar, tebal $10-40 \mathrm{~cm}$. Mengakhiri runtunan batuan, hadir batupasir abu-abu terang hingga abu-abu sangat terang kecoklatan, pejal, perarian sejajar, bergelombang dan flaser, sedikit oksida besi, ukuran sedang - sangat halus, tebal $10-1200 \mathrm{~cm}$, berselingan dengan batulempung abu-abu terang kecoklatan, pejal dan perarian sejajar, tebal $10-40 \mathrm{~cm}$ (Gambar 10), dan sisipan batubara hitam kecoklatan, banded, tebal 20-40 cm (Gambar 11).

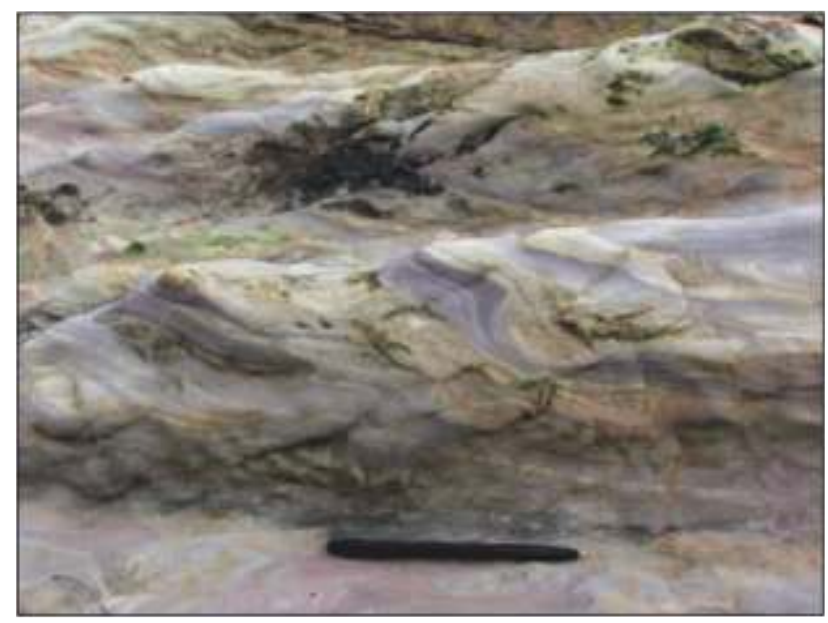

Gambar 7. Batupasir halus hingga sangat halus berstruktur perarian sejajar dan bergelombang penyusun bagian tengah Formasi Tanjung, yang merupakan endapan crevasse splay pada wilayah limpah banjir. 


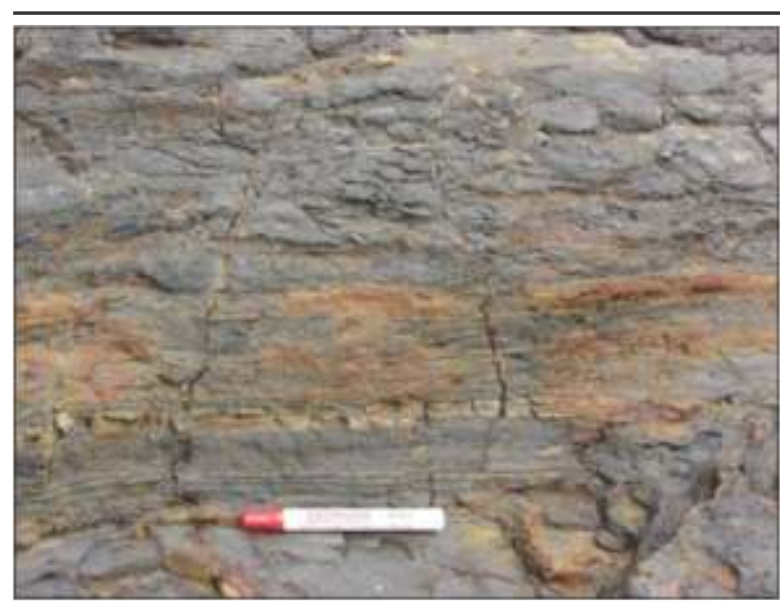

Gambar 8. Batupasir halus hingga sangat halus berstruktur perarian sejajar berselingan dengan batulempung penyusun bagian tengah Formasi Tanjung, yang merupakan endapan limpah banjir pada sistem fluvial.

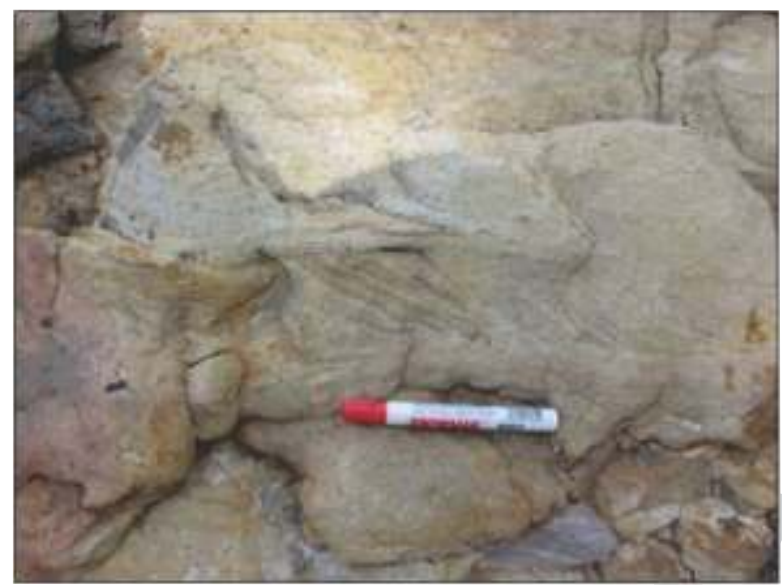

Gambar 9. Batupasir halus berstruktur tulang-ikan penyusun bagian atas Formasi Tanjung, yang merupakan dataran delta dengan pengaruh pasang-surut.

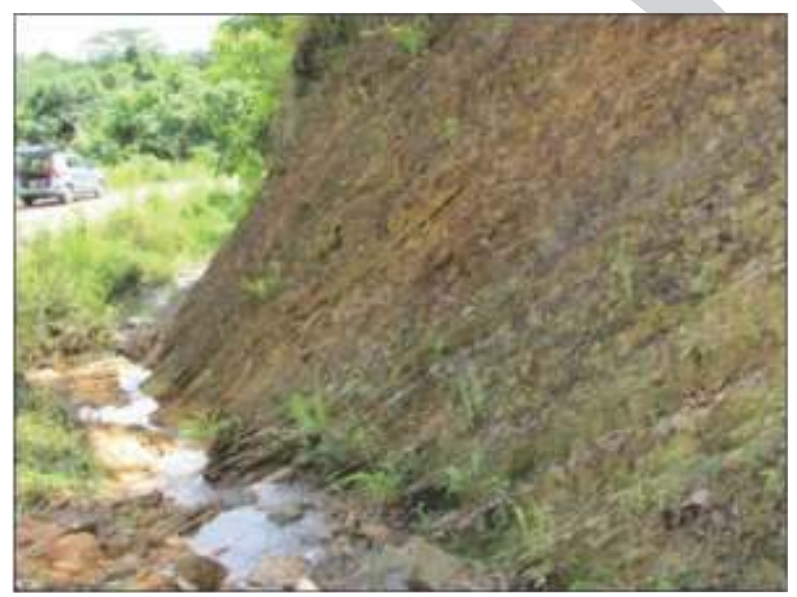

Gambar 10. Batupasir halus berstruktur perarian sejajar berselingan dengan batulempung dan sisipan batubara penyusun bagian atas Formasi Tanjung, yang merupakan endapan cekungan banjir pada dataran delta.

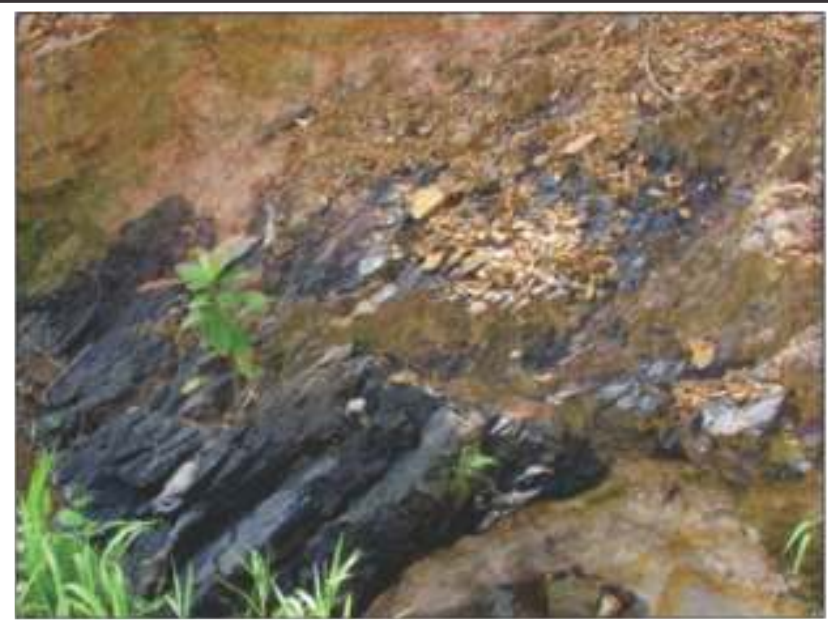

Gambar 11. Lapisan batubara penyusun bagian atas Formasi Tanjung, yang terendapkan di lingkungan cekungan banjir pada dataran delta.

\section{LINGKUNGAN PENGENDAPAN}

Runtunan batuan sedimen klastika penyusun bagian terbawah Formasi Tanjung (Gambar 3a) berupa batupasir yang umumnya kasar hingga halus berstruktur berlapis susun, yang merupakan pengendapan saluran pada sistem fluvial (channel deposit; Miall, 1996). Selanjutnya, batuan berlembang menjadi perselingan batulempung berselingan dengan batupasir halus berstruktur perarian sejajar yang merupakan hasil pengendapan di lingkungan limpah banjir (floodplain) dan sering terganggu oleh crevasse splay akibat jebolnya tanggul alam (levee; Boggs, 1995).

Runtunan batuan sedimen klastika penyusun bagian bawah Formasi Tanjung (Gambar 3b) berupa batupasir berwarna abu-abu terang kecoklatan, berlapis susun tebal yang bagian atasnya menjadi perarian sejajar, dengan bintal oksida besi, bagian bawah lapisan konglomeratan, terpilah buruk, butiran membundar tanggung berukuran mencapai $0,5 \mathrm{~cm}$, tebal $540 \mathrm{~cm}$. Batuan berkembang menjadi batulempung abu-abu terang sedikit kecoklatan, pejal dan beberapa bagian berstruktur perarian sejajar, mengandung bintal oksida besi, tebal 5-100 cm, berselingan dengan batupasir abu-abu sangat terang kecoklatan, ukuran pasir halus hingga sangat halus, struktur perarian sejajar, dengan bintal oksida besi, tebal $5-50 \mathrm{~cm}$ (lihat Gambar 3b). Batupasir berlapis susun, perarian sejajar dan pejal, menghalus ke arah atas ada umumnya merupakan hasil endapan sungai, khususnya wilayah saluran (channel; Boggs, 1995). Perkembangan selanjutnya, batuan berupa batulempung dengan sisipan batupasir halus, merupakan hasil pengendapan di lingkungan limpah banjir (overbank deposit; Evans, 2016), yang sering diganggu banjir. Lingkungan pengendapan ini mengalami perulangan antara limpah banjir dengan beberapa endapan saluran. 


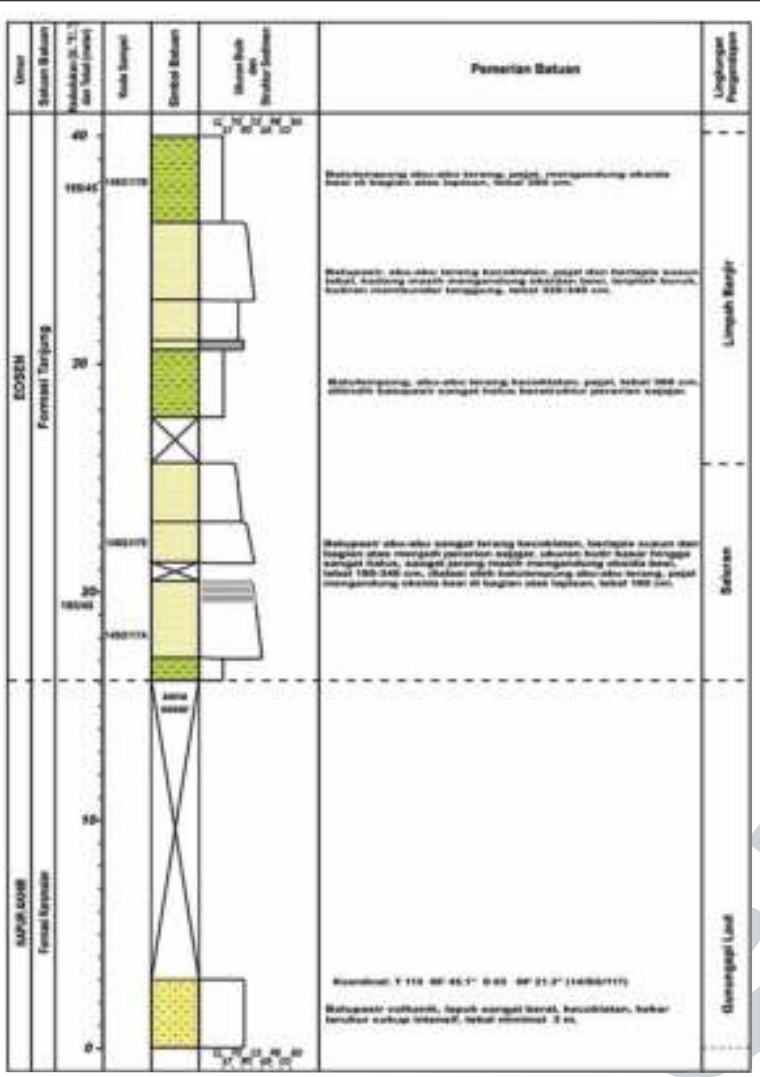

Gambar 3a. Kolom stratigrafi rinci bagian terbawah batuan penyusun Formasi Tanjung yang merupakan endapan sistem fluvial pada saluran dan limpah banjir.

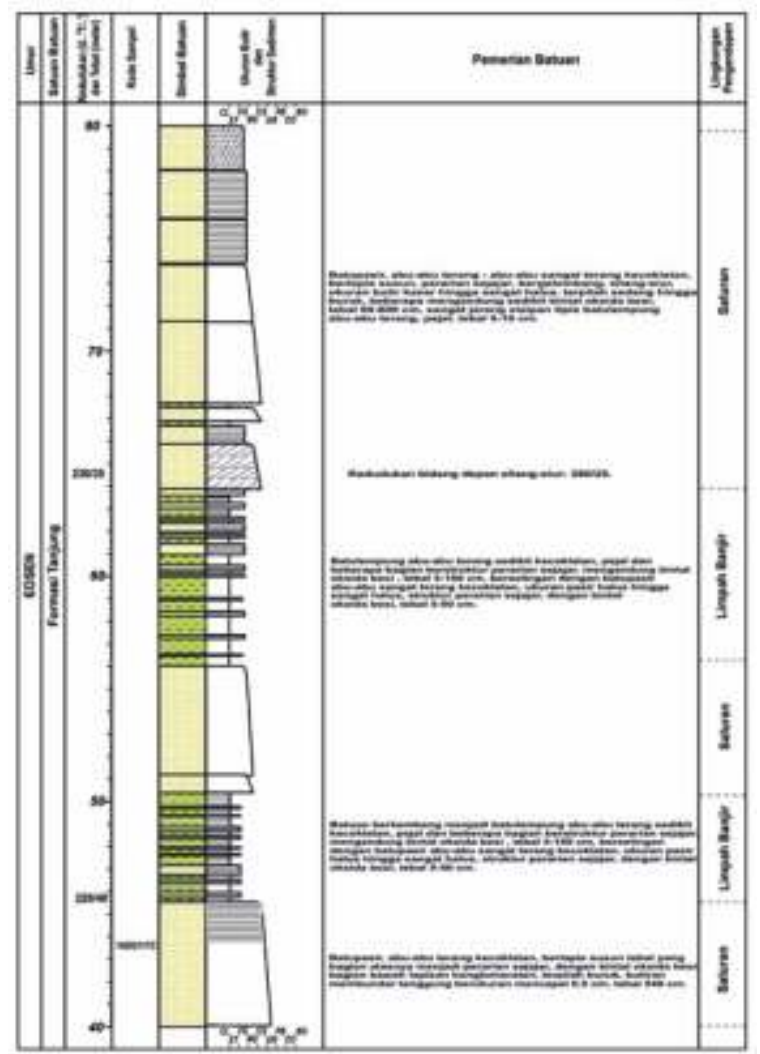

Gambar 3b. Kolom stratigrafi rinci bagian bawah batuan penyusun Formasi Tanjung yang merupakan endapan sistem fluvial dikuasai lingkungan saluran dengan sedikit limpah banjir.
Bagian tengah runtunan batuan (lihat Gambar 3c) sudah dikuasai oleh batulempung dengan sisipan batupasir dengan sisipan batubara. Lingkungan pengendapan batuan seperti ini masih berada di wilayah limpah banjir, khususnya di cekungan banjir (flood basin; Posamentier dan Walker, 2006). Terbatasnya ketebalan sisipan batubara dan sering menyisipnya batupasir berukuran butiran sedang hingga sangat halus mencerminkan sering terganggunya lingkungan cekungan ini akibat banjir. Endapan saluran masih dijumpai di bagian runtunan batuan ini.

Bagian atas runtunan batuan (lihat Gambar 3d) diawali dengan hadirnya batupasir berstruktur perarian sejajar, bergelombang, tulang-ikan, dan flaser, sedikit mengandung bintal oksida besi. Batuan ini masih berselingan dengan batulempung yang kadang-kadang berstruktur perarian sejajar. Sisipan tipis batubara masih dijumpai pada bagian ini. Ragam batuan tersebut masih menunjukkan bahwa lingkungan pengendapan batuan lebih menuju ke laut, meskipun masih berada di lingkungan fluvial, hingga daerah rawa pada dataran delta. Pengaruh laut dicerminkan dengan hadirnya struktur tulang-ikan pada lapisan batupasir. Hal ini masih sesuai dengan pendapat Winantris dkk. (2017) yang menyatakan bahwa batuan sedimen penyusun Formasi Tanjung terendapkan di wilayah rawa dengan pengaruh laut. Lingkungan rawa ini juga teridentifikasi berdasarkan karakteristik batubara pada Formasi Tanjung di daerah Batulicin yang menyatakan lingkungan pengendapannya berada di dataran delta, khususnya wet forest swamp (Heryanto, 2009; Sutjipto, 2020). Berdasarkan karakter batubara dan palinologinya, lingkungan pengendapan batuan yang berada di dataran delta ini pada umumnya dalam kondisi genang laut (Heryanto, 2009).

Penelitian terdahulu mengatakan bahwa batupasir Formasi Tanjung terdiri atas subarkose, feldsphatic litharenite dan sublitharenite, yang bersumber dari lingkungan tektonik recycled orogen dan craton interior (Heryanto dan Margono, 2008). Batuan sumber tersebut diperkirakan dari Komplek Schwaner dan sedikit Jalur Karimunjawa dimulai pada kala Eosen Tengah bagian akhir hingga Oligosen Awal (Witts dkk., 2012). Batuan sumber ini terangkut dan terendapkan di cekungan pengendapan di bagian timur-tenggara. Arah arus purba batuan sedimen klastika ini berlangsung hingga kala Miosen (pengendapan Formasi Warukin) sebelum Pengunungan Meratus terangkat (Witts, 2013). Mengingat lingkungan pengendapan dan jenis batuan Formasi Tanjung, batuan sedimen formasi ini bisa berfungsi sebagai batuan sumber hidrokarbon (Doust dan Noble, 2008), khususnya pada sisipan batubara di Cekungan Barito (Heryanto, 2014). 


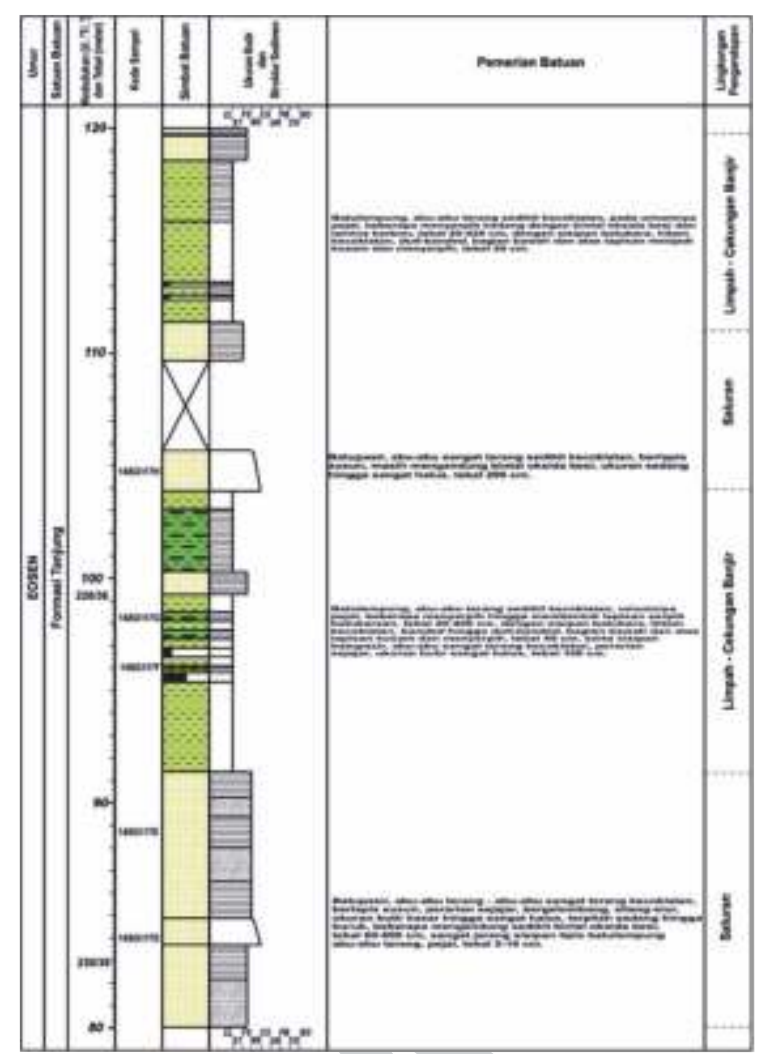

Gambar 3c. Kolom stratigrafi rinci bagian tengah batuan penyusun Formasi Tanjung yang merupakan endapan sistem fluvial dikuasai lingkungan limpah - cekungan banjir dengan beberapa saluran.

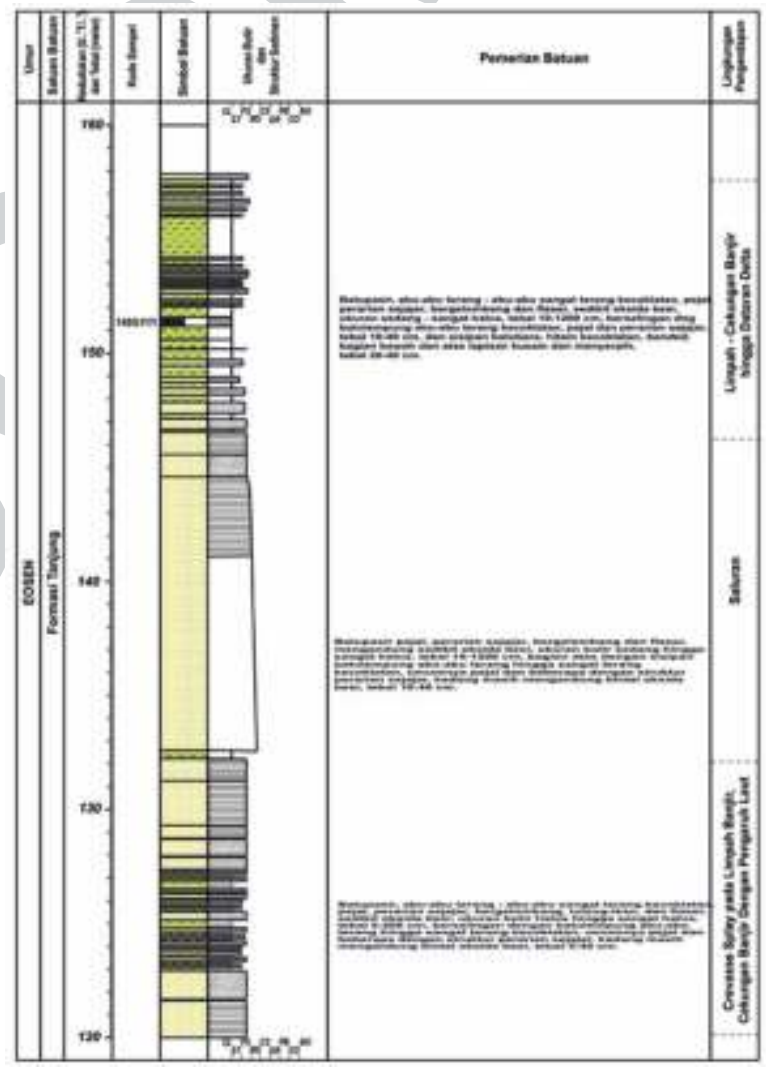

Gambar 3d. Kolom stratigrafi rinci bagian atas batuan penyusun Formasi Tanjung yang merupakan endapan sistem fluvial pada lingkungan crevasse splay dan limpah - cekungan banjir pada dataran delta dengan pengaruh laut dan diselingi endapan saluran. 


\section{KESIMPULAN}

Batuan sedimen klastika penyusun Formasi Tanjung awalnya merupakan hasil endapan sungai, khususnya endapan saluran dan limpah banjir. Lingkungan pengendapan berkembang menjadi wilayah limpah banjir, khususnya di cekungan banjir yang sering terganggu akibat banjir. Selanjutnya, lingkungan pengendapan batuan cenderung ke laut, meskipun masih berada di lingkungan fluvial, hingga daerah rawa pada dataran delta dengan pengaruh laut. Batuan sumber formasi ini terangkut dan terendapkan di cekungan pengendapan di bagian timur-tenggara.

\section{UCAPAN TERIMAKASIH}

Ucapan terimakasih disampaikan kepada Sdr. Vincent Silitonga dan Sdr. Andi Sufian Yusuf, atas bantuannya selama dilakukan pengambilan data di lapangan. Terimakasih yang tulus diucapkan kepada Sdr. Herwin Syah selaku teknisi laboratorium atas bantuan pendigitan gambar.

\section{ACUAN}

Boggs, S.Jr., 1995. Principles of Sedimentology and Stratigraphy. Prentice Hall, New Jersey: 774 p.

Dirk, M.H.J. dan Amiruddin., 2009. Batuan Granitoid. Dalam: Hartono, Sukamto, Surono dan Panggabean (Ed.). Evolusi magmatik Kalimantan Selatan. Publikasi Khusus Pusat Survei Geologi 23: 37-51.

Doust, H. and Noble, R.A., 2008. Petroleum System of Indonesia. Marine and Petroleum Geology, 25: 103-129.

Evans, J.E., 2016. Fluvial Environments. In book: Encyclopedia of Engineering Geology, pp.1-7. Springer International Publishing, DOI:10.1007/978-3-319-12127-7_129-1

Heryanto, R., 2014. Batubara Formasi Tanjung Sebagai Batuan Sumber Hidrokarbon di Cekungan Barito. Jurnal Geologi dan Sumberdaya Mineral, 15(3): 105-115.

Heryanto, R., 2010. Geologi Cekungan Barito, Kalimantan. Badan Geologi, Kementerian Energi dan Sumber Daya Mineral, Bandung. $139 \mathrm{~h}$.

Heryanto, R., 2009. Karakteristik dan Lingkungan Pengendapan Batubara Formasi Tanjung di Daerah Binuang dan Sekitarnya, Kalimantan Selatan. Jurnal Geologi Indonesia, 4: 239-252.

Heryanto, R. and Margono, U., 2008. The Provenance and Diagenesis of Sandstones of the Eocene Tanjung Formation in the Kualakurun Area, Central Kalimantan. Geological Resources Journal, 18(5): 291-298.

Heryanto, R., Sutrisno, Sukardi, dan Agustiyanto, D.A., 1998. Peta Geologi Lembar Belimbing, Kalimantan, Skala 1:100.000. Pusat Penelitian dan Pengembangan Geologi, Bandung.

Kusumah, K.D., Jamal, dan Maryanto, S., 2016. Peta Geologi Lembar Binuang(1712-62) Kalimantan Skala 1:50.000. Pusat Survei Geologi Bandung.

Margono, U., 2012. Penyusunan Stratigrafi di Daerah Binuang dan sekitarnya, Kalimantan Selatan. Laporan Teknis Intern, Pusat Survei Geologi Bandung (tidak dipublikasikan).

Margono, U., Sutrisno, dan Susanto, E., 1997. Peta Geologi Lembar Kandangan, Kalimantan Selatan Skala 1:100.000. Pusat Penelitian dan Pengembangan Geologi Bandung.

Maryanto, S., Jamal, dan Kusumah, K.D, 2014. Mikrofasies Batugamping Formasi Batununggal di Daerah Binuang, Kalimantan Selatan. Jurnal Geologi dan Sumberdaya Mineral, 15: 195-204.

Miall, A.D., 1992. Alluvial Deposits, in Walker, R.G. and James, N.P. (eds.)., Facies Models, Response to Sea Level Change. Geol. Assoc. Canada, 119-142.

Posamentier, H.W. and Walker, R.G., 2006. Facies Models Revisited. SEPM Special Publication 84, Tulsa Oklahoma USA.

Setiawan, N.I., Osanai, Y., Nakano, N., Adachi, T., and Asy'ari, A., 2015. Metamorphic evolution of garnet-bearing epidote-barroisite schist from the Meratus complex in South Kalimantan, Indonesia. Indonesian Journal on Geoscience, 2: 139-156.

Sunarjanto, D. and Widjaja, S., 2013. Potential Development of Hydrocarbon in Basement Reservoir in Indonesia. Indonesian Journal of Geology, 8: 151-161. 
Sutjipto, R.H., 2020. Karakteristik dan Lingkungan Pengendapan Batubara Formasi Tanjung di Daerah Batulicin, Kalimantan Selatan. Jurnal Geologi dan Sumberdaya Mineral, 21(3): 157-164.

Winantris, Hamdani, H., and Harlia, E., 2017. Paleoenvironment of Tanjung Formation Barito Basin, Central Kalimantan Based on Palynological Data. Journal of Geoscience, Engineering, Environment, and Technology, 02(02): 110-116.

Witts, D., Hall, R., Nicols,G., and Morley, R.J., 2012. A New Depositional and Provenance Model for the Tanjung Formation, Barito Basin, SE Kalimantan, Indonesia. Journal of Asian Earth Science, 56: 77-104.

Witts, D., 2013. Paleocurrents and Provenance: Uplift History of the Meratus Complex, SE Kalimantan. Indonesian Journal of Sedimentary Geology, 12(28): 25-30. ISBN:0853-9413. 